\title{
Upaya Meningkatkan Hasil Belajar Matematika Melalui Model Pembelajaran Kooperatif Tipe STAD Siswa Kelas V.A SD Negeri 146/IX Parit Kecamatan Sungai Gelam
}

\author{
Makhrus \\ Guru SD Negeri 146/IX Parit \\ Correspondence email: makhrus1966@gmail.com
}

\begin{abstract}
Abstrak. Penelitian ini bertujuan untuk mengungkapkan informasi dan membahas tentang Upaya Meningkatkan Hasil Belajar Matematika Melalui Model Pembelajaran Kooperatif Tipe STAD Siswa Kelas V.A SD Negeri 146/IX Parit ecamatan Sungai Gelam. Penelitian ini termasuk dalam jenis penelitian tindakan kelas (PTK). Penelitian ini dilaksanakan di SD Negeri 146/IX Parit Kecamatan Sungai Gelam. Waktu penelitian ini dilaksanakan semester genap tahun pelajaran 2018/2019, dimulai pada bulan Januari 2019. Subjek dalam penelitian ini adalah siswa kelas V.A SD Negeri 146/IX Parit Kecamatan Sungai Gelam yang berjumlah 20 orang. Prosedur penelitian terdiri dari dua siklus dengan masing-masing siklus dua kali pertemuan. Setiap siklus terdiri atas empat tahap penelitian yaitu perencanaan, pelaksanaan, observasi dan refleksi. Pengumpulan data dalam penelitian ini dilakukan dengan menggunakan catatan lapangan, lembar kerja siswa, tes tertulis, dan dokumen Teknik analisis data menggunakan rumus persentase dan reduksi data. Hasil penelitian ini menunjukkan bahwa Model Pembelajaran Kooperatif Tipe STAD dapat meningkatkan hasil belajar matematika siswa dengan tindakan memberikan hadiah.
\end{abstract}

Kata Kunci: Hasil Belajar Matematika; Model Pembelajaran Kooperatif Tipe STAD

Abstract. This research aims to reveal information and discuss about efforts to improve mathematics learning outcomes through cooperative learning model type stad students grade V.A SD Negeri 146/IX Parit Sungai Gelam sub-district. This research is included in this type of class action research (PTK). This research was conducted at SD Negeri 146/IX Parit Sungai Gelam SubDistrict. The study was conducted in the even semester of the 2018/2019 school year, starting in January 2019. The subjects in this study were students of Grade V.A. SD Negeri 146/IX Parit Sungai Gelam Sub-District which numbered 20 people. The research procedure consists of two cycles with each cycle twice meeting. Each cycle consists of four stages of research namely planning, implementation, observation and reflection. The data collection in this study was conducted using field records, student worksheets, written tests, and data analysis techniques using percentage formulas and data reduction. The results of this study show that the STAD Type Cooperative Learning Model can improve students' math learning outcomes by rewarding actions.

Keywords: Math Learning Results; STAD Type Cooperative Learning Model

\section{PENDAHULUAN}

Pendidikan adalah usaha sadar dan terencana untuk mewujudkan suasana belajar dan proses pembelajaran agar peserta didik secara aktif mengembangkan potensi dirinya untuk memiliki kekuatan spiritual keagamaan, pengendalian diri, kepribadian, kecerdasan, akhlak mulia, serta keterampilan yang diperlukan dirinya, masyarakat bangsa dan Negara. (UU Sisdiknas No 20/2003).

Berdasarkan Undang-Undang Nomor 14 Tahun 2005 tentang guru dan dosen. Guru adalah pendidik professional dengan bertugas melaksanakan itu semua serta mendidik, mengajar, membimbing, mengarahkan, melatih, menilai dan mengevaluasi peserta didik pada anak usia dini jalur pendidikan formal, pendidikan dasar dan pendidikan menengah.

Menurut Permendiknas Nomor 22 Tahun 2006 tantang Standar Isi, matematika merupakan ilmu universal yang mendasari perkembangan teknologi modern, mempunyai peran penting dalam berbagai displin dan memajukan daya pikir manusia. Perkembangan pesat di bidang teknologi informasi dan komunikasi dewasa ini dilandasi oleh perkembangan matematika dibidang teori bilangan, aljabar, analisis, teori peluang dan matematika diskrit. Untuk mengusasi dan mencipta teknologi di masa depan diperlukan penguasaan matematika yang kuat sejak dini.

Mata pelajaran matematika perlu diberikan kepada semua peserta didik mulai dari sekolah dasar untuk membekali peserta didik dengan kemampuan berpikir logis, analitis, sistematis, kritis, dan kreatif, serta kemampuan bekerjasama. Kompetensi tersebut diperlukan agar peserta didik dapat memiliki kemampuan memperoleh, mengelola, dan memanfaatkan informasi untuk bertahan hidup pada keadaan yang selalu berubah, tidak pasti, dan kompetitif.

Berdasarkan atas evaluasi peneliti selama mengajar di SD Negeri 146/IX Parit terdapat beberapa kendala dalam pencapaian hasil belajar yang optimal. Dari beberapa kali diberikan penilaian ternyata hasil belajarnya masih tetap rendah walau telah diberikan berbagai metode atau model pembelajaran. Bidang kajian peneliti ini adalah rendahnya hasil belajar siswa untuk mata pelajaran Matematika di SD Negeri 146/IX Parit. Untuk meningkatkan hasil belajar siswa tersebut secara maksimal, maka perlu perbaikan model 
pembelajaran yaitu melalui Model Pembelajaran Kooperatif tipe STAD.

Penelitian ini dilakukan untuk memecahkan masalah yang selama ini menyebkan guru resah, gelisah dengan banyaknya nilai siswa tidak tuntas sesuai dengan nilai ketuntasan minimal (KKM). Padahal guru selama ini telah menerapkan yang namanya pembelajaran kontekstual, dimana pusat pembelajaran sudah berada pada siswa dan guru hanya sebagai pemotifator dan fasilitator.

Kemudian berbagai model pembelajaran langsung dan strategi life skil juga sudah diterapkah, namun hasil belajar siswa belum memuaskan secara klasikal. Hal ini terbukti dari data ulangan harian siswa, masih terdapat banyak siswa yang di bawah KKM (70) yaitu (5 Siswa) yang mendapatkan nilai di atas KKM (70) dari 20 siswa kelas V.A SD Negeri 146/IX Parit.

Jadi rendahnya nilai siswa inilah yang membuat keresahan guru. Setelah diselidiki dan dicoba-coba mencari akar permasalahannya maka guru beranggapan model pembelajaran harus divariasikan jangan hanya ingquiri. Untuk itu guru akan mencoba memberi kan model pembelajaran lain yang bernama Kooperatif tipe STAD. Karena hal ini tidak bisa didiamkan dan harus segera diberikan tindakan. Maka penulis selaku seorang guru Matematika merasa terpanggil dan termotivasi untuk menelitinya.

Menurut James O. Whittaker (dalam Abu Ahmadi dan Widodo Supriyono, 1991), belajar dapat didefinisikan sebagai proses di mana tingkah laku ditimbulkan atau diubah melalui latihan atau pengalaman ("Learning may be difined as the process by which behavior originates or is altered through training or experience"). Menurut Winarno Surakhmad (1980), belajar dapat dipandang sebagai hasil, sebagai proses dan sebagai sebuah fungsi.

Belajar merupakan salah satu faktor yang mempengaruhi dan berperan penting dalam pembentukan pribadi dan perilaku individu. Nana Syaodih Sukmadinata (2005) menyebutkan bahwa sebagian terbesar perkembangan individu berlangsung melalui kegiatan belajar.

Hasil belajar adalah segala sesuatu yang dapat dilakukan atau dikuasai siswa sebagai hasil pembelajaran (Nasution 1999). Sedangkan menurut Sudjana (2002) Hasil belajar adalah kemampuan yang dimiliki siswa setelah ia menerima pengalaman belajarnya. Hasil belajar terwujud dalam perubahan tingkah laku dari tidak tahu menjadi tahu dan dari tidak mengerti menjadi mengerti.

Hal ini sejalan dengan yang diungkapkan Arikunto (1992) yang menjelaskan bahwa" Tujuan penilaian hasil belajar adalah untuk mengetahui apakah materi yang sudah diberikan mudah dipahami oleh siswa dan apakah metode yang digunakan sudah te pat atau belum.
Mata pelajaran matematika perlu diberikan kepada semua peserta didik mulai dari sekolah dasar untuk membekali peserta didik dengan kemampuan berpikir logis, analitis, sistematis, kritis, dan kreatif, serta kemampuan bekerjasama.Kompetensi tersebut diperlukan agar peserta didik dapat memiliki kemampuan memperoleh, mengelola, dan memanfaatkan informasi untuk bertahan hidup pada keadaan yang selalu berubah, tidak pasti, dan kompetitif.

Penggunaan model mengajar sangat bergantung pada guru sebagai pemegang manajemen kelas dan sekaligus akan menentukan berhasil tidaknya pencapaian tujuan yang hendak dicapai. Menurut S. Nasution (1987) mengatakan bahwa: "Mengajar belajar adalah kegiatan guru dan murid untuk mencapai tujuan. tertentu. Diduga semakin jelas tujuan semakin jelas kemungkinankemungkinannya ditemukan model yang serasi. Namun tidak ada, pegangan yang pasti cara mendapatkan model mengajar yang paling tepat. Tetapi baik tidaknya suatu metode mengajar baru terbukti dari hasil belajar murid. Bila hasil belajar murid tercapai, maka, dianggap telah terjadi proses belajar mengajar yang tepat". Jadi model pembelajaran adalah cara guru dalam penyampain materi, guru hanya sebagai fasilitator dan siswa lah yang aktif dalam kegiatan pembelajaran . Sehingga dalam dalam memilih model pembelajaran yang tepat haruslah memperhatikan kondisi siswa, sifat materi bahan ajar, fasilitas-media yang tersedia, dan kondisi guru itu sendiri.

Pembelajaran Koopratif Tipe STAD yang dimaksud adalah model pembelajaran yang mempersyaratkan siswa membentuk kelompok yang beranggotakan empat orang setiap kelompoknya. Menurut Adesanjaya (2011) kelebihan model pembelajaran kooperatif tipe STAD yaitu 1. Memberikan kesempatan kepada siswa untuk menggunakan keterampilan bertanya dan membahas suatu masalah. 2. Memberikan kesempatan kepada siswa untuk lebih intensif mengadakan penyelidikan mengenai suatu masalah. 3. Mengembangkan bakat kepemimpinan dan mengajarkan keterampilan berdiskusi. 4. Memberikan kesempatan kepada siswa untuk mengembangkan rasa menghargai, menghormati pribadi temannya, dan menghargai pendapat orang lain.

Model pembelajaran STAD termasuk model pembelajaran kooperatif.Sebagaimana yang diungkapkan oleh Slavin "pembelajaran kooperatif tipe STAD, peserta didik dikelompokkan dalam kelompok belajar yang beranggotakan empat atau lima orang peserta didik yang merupakan campuran dari kemampuan akademik yang berbeda, sehingga setiap kelompok terdapat peserta didik yang berprestasi tinggi, sedang, dan rendah".

Jadi, model pembelajaran STAD adalah kegiatan belajar kelompok, dan hasil dari diskusi kelompok akan dipertanggung jawabkan secara mandiri oleh setiap siswa 


\section{METODE}

\section{Bentuk penelitian}

Penelitian ini merupakan penelitian tindakan kelas (PTK) dengan tujuan untuk memperbaiki dan meningkatkan mutu praktek-praktek pembelajaran. Menurut Arikunto (2002) bahwa penelitian tindakan kelas adalah penelitian tindakan (action research) yang dilakukan dengan tujuan memperbaiki mutu praktek pembelajaran di kelas.

Penelitian tindakan kelas dilaksanakan dalam bentuk siklus berulang yang didalamnya terdapat empat tahap utama yaitu perencanaan, tindakan/pelaksanaan, pengamatan/observasi dan refleksi.

\section{Subjek penelitian}

Penelitian ini dilaksanakan di SD Negeri 146/IX Parit Kecamatan Sungai Gelam. Waktu penelitian ini dilaksanakan pada semester 2 bulan Januari 2019 tahun pelajaran 2018 - 2019. Subjek yang dimaksud tindakan dalam penelitian ini adalah siswa kelas V.A SD Negeri 146/IX Parit Kecamatan Sungai Gelam yang berjumlah 20 siswa.

\section{Prosedur penelitian}

Prosedur penelitian terdiri dari dua siklus dengan tiap siklus dua kali pertemuan dengan masing-masing siklus empat tahap pelaksanaan mulai dari perencanaan, pelaksanaan, observasi dan refleksi.

\section{Istrumen Penelitian}

Pengumpulan data dalam penelitian ini dilakukan dengan menggunakan teknik catatan lapangan, lembar kerja siswa, tes tertulis, dan dokumen.

\section{Teknik Pengumpulan data}

Analisis data dalam penelitian ini melalui paparan data, dan penyimpulan hasil analisis. Untuk menghitung persentasi hasil belajar siswa peneliti menggunakan rumus:

Ketercapaian indikator siswa $=\frac{\text { skor yang diperoleh }}{\text { skor maksimal }} \times 100$

\section{HASIL DAN PEMBAHASAN}

Siklus 1

\section{Perencanaan}

Persiapan yang dilakukan pada perencanaan siklus I adalah sebagai berikut: Mempersiapkan silabus. Membuat Rencana Pelaksanaan Pembelajaran (RPP) siklus I yang bercirikan pembelajaran menggunakan model STAD. Mempersiapkan bahan ajar. Mempersiapkan media pembelajaran. Mempersiapkan soal ulangan harian dan kunci jawaban. Mempersiapkan angket. Mempersiapkan catatan lapangan siklus I.
Pertemuan Pertama pada siklus 1 dilaksanakan pada Selasa 8 Januari 2019 dikelas V.A SD Negeri 146/IX Parit jam pelajaran 7:30-8:40 dengan jumlah siswa sebanyak 20 orang. Materi pembelajaran pada pertemuan pertama ini adalah mengubah pecahan biasa ke persen dan desimal atau sebaliknya. Mengubah persen ke pecahan biasa. Pelaksaan penelitian berdasarkan rencana pembelajaran mulai dari pendahuluan, kegiatan inti dan penutup.

\section{Pertemuan Kedua}

Pertemuan kedua pada siklus 1 dilaksanakan pada Rabu 11 Januari 2019 di kelas V.A SD Negeri 146/IX Parit jam pelajaran 7:30-8:40 dengan jumlah siswa sebanyak 20 orang. Materi pembelajaran pada pertemuan pertama ini adalah mengubah pecahan biasa ke persen dan desimal atau sebaliknya. Mengubah persen ke pecahan biasa. Pelaksaan penelitian berdasarkan rencana pembelajaran mulai dari pendahuluan, kegiatan inti dan penutup.

\section{Observasi}

Pada akhir proses belajar mengajar siswa diberi tes formatif dengan tujuan untuk mengetahui tingkat keberhasilan siswa dalam proses belajar mengajar yang telah dilakukan. Adapun data hasil penelitian pada siklus I adalah sebagai berikut:

Tabel 1. Rekapitulasi Ketuntasan Belajar Siswa Siklus I

\begin{tabular}{|l|c|c|}
\hline \multicolumn{1}{|c|}{ Hasil Belajar } & Nilai/jumlah & Persentase \\
\hline Jumlah Siswa Yang Tuntas & 10 Orang & $50 \%$ \\
\cline { 1 - 2 } $\begin{array}{l}\text { Jumlah Siswa Yang Belum } \\
\text { Tuntas }\end{array}$ & 10 Orang & $50 \%$ \\
\hline Jumlah Nilai & $\mathbf{1 3 9 5}$ & \\
\hline Rata-rata & $\mathbf{6 9 , 7 5}$ & \\
\cline { 1 - 2 } KKM & $\mathbf{7 0}$ & \\
\hline
\end{tabular}

\section{Rekapitulasi Ketuntasan Belajar Siswa}

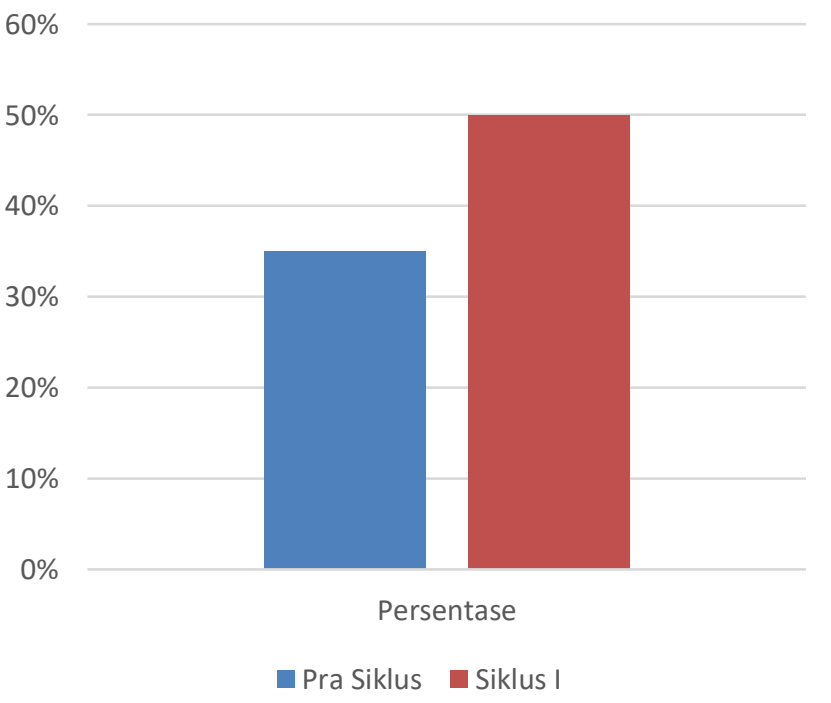

Gambar 1. Rekapitulasi Ketuntasan Belajar Siswa Siklus I 
Dari tabel dan grafik di atas dapat dijelaskan bahwa dengan menerapkan model pembelajaran kooperatif tipe STAD (Student Teams Achievement Division) diperoleh nilai rata-rata hasil belajar siswa adalah 69,75 dan ketuntasan belajar mencapai 50\% atau ada 10 siswa dari 20 siswa sudah tuntas belajar. Hasil tersebut menunjukkan bahwa pada siklus pertama secara klasikal siswa belum tuntas belajar, karena siswa yang memperoleh nilai $\geq 70$ hanya sebesar $50 \%$ lebih kecil dari persentase ketuntasan yang dikehendaki yaitu sebesar $80 \%$. Hal ini disebabkan karena siswa masih merasa baru dan belum mengerti apa yang dimaksudkan dan digunakan guru dengan menerapkan model pembelajaran kooperatif tipe STAD (Student Teams Achievement Division).

\section{Siklus II \\ Perencanaan}

Persiapan yang dilakukan pada perencanaan siklus I adalah sebagai berikut: Mempersiapkan silabus. Membuat Rencana Pelaksanaan Pembelajaran (RPP) siklus II yang bercirikan pembelajaran menggunakan model STAD. Mempersiapkan bahan ajar. Mempersiapkan media pembelajaran. Mempersiapkan soal ulangan harian dan kunci jawaban. Mempersiapkan angket. Mempersiapkan catatan lapangan siklus II. Menyiapkan hadiah

\section{Pelaksanaan}

Pertemuan Pertama

Pertemuan pertama pada siklus 2 dilaksanakan pada selasa 15 Januari 2019 di kelas V.A SD Negeri 146/IX Parit jam pelajaran 7:30-8:40 dengan jumlah siswa sebanyak 20 orang. Materi pembelajaran pada pertemuan pertama ini adalah mengubah pecahan biasa ke persen dan desimal atau sebaliknya. Mengubah persen ke pecahan biasa. Pelaksaan penelitian berdasarkan rencana pembelajaran mulai dari pendahuluan, kegiatan inti dan penutup.

\section{Pertemuan Kedua}

Pertemuan kedua pada siklus 2 dilaksanakan pada selasa 18 Januari 2019 di kelas V.A SD Negeri 146/IX Parit jam pelajaran 5-6 dengan jumlah siswa sebanyak 20 orang. Materi pembelajaran pada pertemuan pertama ini adalah mengubah pecahan biasa ke persen dan desimal atau sebaliknya. Mengubah persen ke pecahan biasa. Pelaksaan penelitian berdasarkan rencana pembelajaran mulai dari pendahuluan, kegiatan inti dan penutup.

\section{Observasi}

Pada akhir proses belajar mengajar siswa diberi tes formatif dengan tujuan untuk mengetahui tingkat keberhasilan siswa dalam proses belajar mengajar yang telah dilakukan. Adapun data hasil penelitian pada siklus II adalah sebagai berikut:

Tabel 2. Rekapitulasi Ketuntasan Belajar Siswa Siklus II

\begin{tabular}{|c|c|c|}
\hline Hasil Belajar & Nilai/jumlah & Persentase \\
\hline Jumlah Siswa Yang Tuntas & 17 Orang & $85 \%$ \\
\hline $\begin{array}{l}\text { Jumlah Siswa Yang Belum } \\
\text { Tuntas }\end{array}$ & 3 Orang & $15 \%$ \\
\hline Jumlah Nilai & 1560 & \\
\hline Rata-rata & 78 & \\
\hline KKM & 70 & \\
\hline
\end{tabular}

\section{Rekapitulasi Ketuntasan Belajar Siswa}

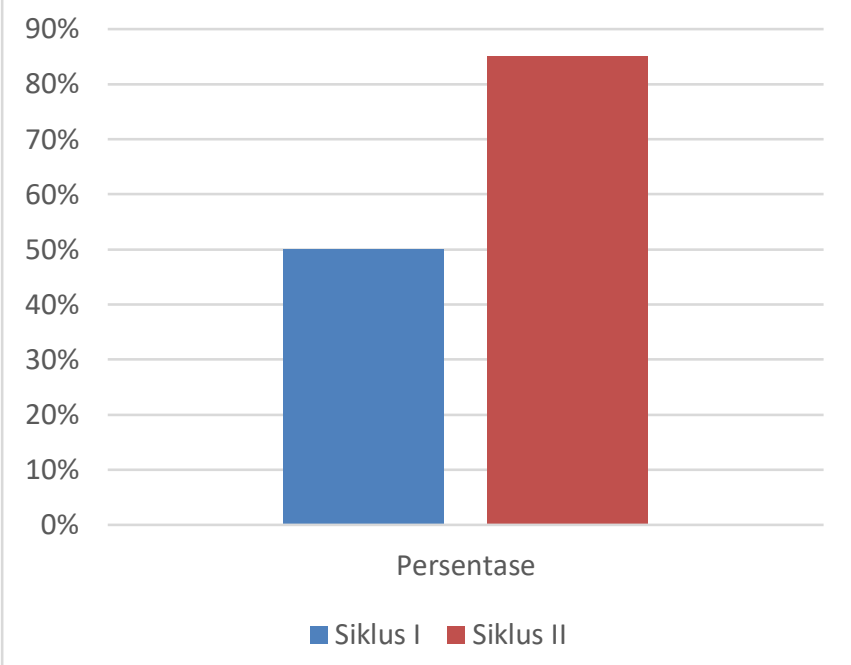

Gambar 2. Rekapitulasi Ketuntasan Belajar Siswa Siklus II

Dari tabel di atas dapat dijelaskan bahwa dengan menerapkan model pembelajaran kooperatif tipe STAD (Student Teams Achievement Division) diperoleh nilai rata-rata hasil belajar siswa adalah 78 dan ketuntasan belajar mencapai $85 \%$ atau ada 17 siswa dari 20 siswa sudah tuntas belajar. Hasil tersebut menunjukkan bahwa pada siklus pertama secara klasikal siswa belum tuntas belajar, karena siswa yang memperoleh nilai $\geq 70$ hanya sebesar $85 \%$ sudah mencapai persentase ketuntasan yang dikehendaki yaitu sebesar $80 \%$. Hal ini disebabkan karena siswa masih merasa baru dan belum mengerti apa yang dimaksudkan dan digunakan guru dengan menerapkan model pembelajaran kooperatif tipe STAD (Student Teams Achievement Division).

\section{Pembahasan}

Melalui hasil peneilitian ini menunjukkan bahwa model pembelajaran kooperatif tipe STAD (Student Teams Achievement Division) memiliki dampak positif dalam meningkatkan hasil belajar siswa. Hal ini dapat dilihat dari semakin mantapnya pemahaman siswa terhadap materi yang disampaikan guru ketuntasan belajar meningkat dari pra siklus, siklus I, dan II yaitu masing-masing $35 \%, 50 \%$ dan $85 \%$. 


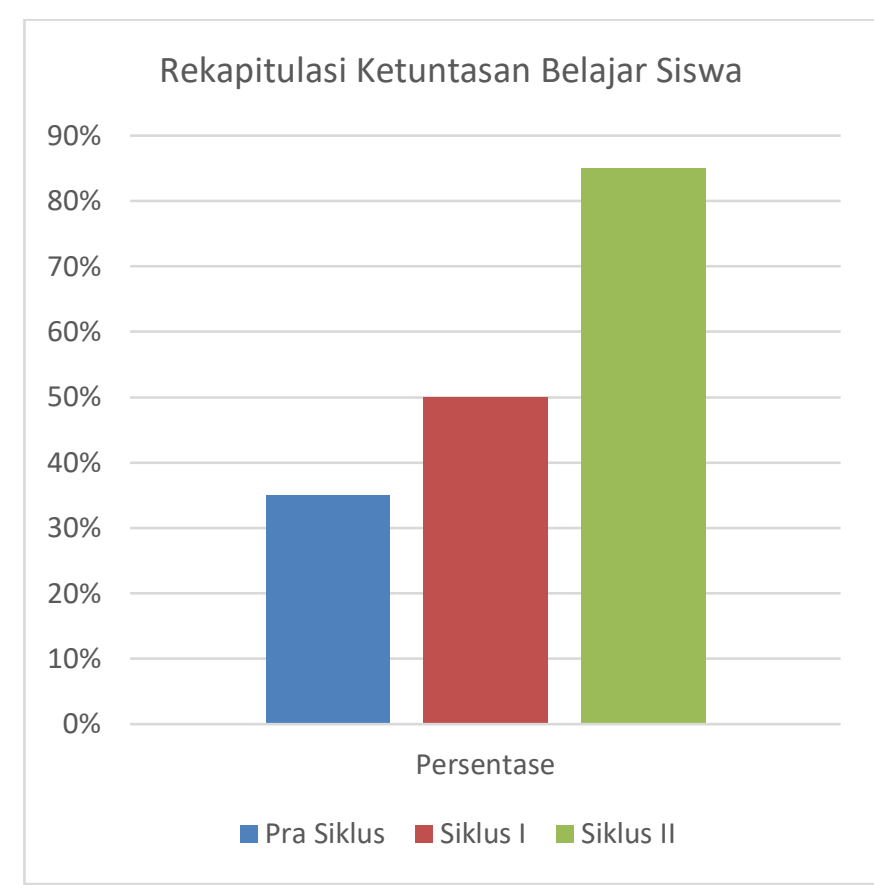

Gambar 3. Ketuntasan belajar meningkat dari pra siklus, siklus I, dan II

Pada siklus II ketuntasan belajar siswa secara klasikal telah tercapai. Model pembelajaran STAD termasuk model pembelajaran kooperatif. Sebagaimana yang diungkapkan oleh Slavin "pembelajaran kooperatif tipe $S T A D$, peserta didik dikelompokkan dalam kelompok belajar yang beranggotakan empat atau lima orang peserta didik yang merupakan campuran dari kemampuan akademik yang berbeda, sehingga setiap kelompok terdapat peserta didik yang berprestasi tinggi, sedang, dan rendah".

\section{SIMPULAN}

Dari hasil kegiatan pembelajaran yang telah dilakukan selama dua siklus, dan berdasarkan seluruh pembahasan serta analisis yang telah dilakukan dapat disimpulkan sebagai berikut:

1. Pembelajaran dengan model pembelajaran kooperatif tipe STAD (Student Teams Achievement Division) memiliki dampak positif dalam meningkatkan hasil belajar siswa yang ditandai dengan peningkatan ketuntasan belajar siswa dalam setiap siklus, yaitu pra siklus (35\%), siklus I (50\%) dan siklus II (85\%).

2. Penerapan model pembelajaran kooperatif tipe STAD (Student Teams Achievement Division) mempunyai pengaruh positif, yaitu dapat meningkatkan hasil belajar siswa yang ditunjukan dengan rata-rata jawaban siswa yang menyatakan bahwa siswa tertarik dan berminat dengan model pembelajaran kooperatif tipe STAD (Student Teams Achievement Division) sehingga mereka menjadi termotivasi untuk belajar.

\section{DAFTAR PUSTAKA}

Ahmadi, Abu dan Widodo Supriyono. 1991. Psikologi Belajar. Jakarta: Rineka Cipta.

Arikunto, Suharsimi. 1992. Prosedur Penelitian Suatu Pendekatan Praktik. Jakarta: Rineka Cipta.

Arikunto, Suharsimi. 2002. Dasar-Dasar Evaluasi Pendidikan (Edisi Revisi). Jakarta: Bumi Aksara

Arikunto, Suharsimi. 2002. Prosedur Penelitian Suatu Pendekatan Praktek. Jakarta: Rineka Cipta

Adesanjaya. 2011. "Pemanfaatan Media Gambar dalam Proses Belajar Mengajar". http:// Adesanjaya.blogspot.com diakses pada tanggal 25 Maret 2015 pukul 22.05 WIB.

Nana Syaodih Sukmadinata. 2005. Metode Penelitian Pendidikan. Bandung: Remaja Rosda Karya.

Nasution, 1987. Berbagai Pendekatan Dalam Proses Belajar Mengajar. Jakarta: PT. Bumi Aksara

Sudjana, Nana. 2002. Dasar-Dasar Proses Belajar Mengajar. Bandung: Sinar Baru Algesindo

Sudjana, Nana. 2002. Penilaian Hasil Proses Belajar Mengajar.Bandung: remaja Rosdakarya.

UU Sisdiknas No 20/2003

Undang-Undang Nomor 14 Tahun 2005

Permendiknas Nomor 22 Tahun 2006 